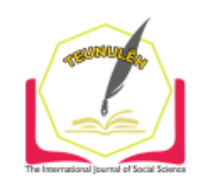

Jurnal Ilmiah Teunuleh

The International Journal of Social Sciences

Vol. 1, Issue. 2, Dec 2020

E-ISSN: 2746-4393

\title{
THE ROLE OF SOCIAL MEDIA IN MARKETING OF MICRO, SMALL, AND MEDIUM ENTERPRISES (MSMES) PRODUCT DURING COVID 19 PANDEMIC
}

\author{
Arifah Hidayati ${ }^{1}$ \\ Melvi Yansi \\ ${ }^{12}$ Prof. Dr. Hazairin University \\ ${ }^{1}$ arreefa@gmail.com²melviyansi@gmail.com
}

\begin{abstract}
This study aims to explain how the role of social media in marketing MSME products during the Covid 19 pandemic in DKI Jakarta. This research method is qualitative by using phenomenological predictions. The results of this study explain that MSMEs are more dominant in using the TikTok, Instagram, Facebook, and WhatsApp applications in promoting their products because they are easier to implement and can attract more consumer interest through interesting videos and photos. Therefore, social media provides a good prospect for increasing the sales of MSME products in DKI Jakarta which is experiencing the impact of the COVID-19 pandemic. This is because the digital marketing system provides an online buying and selling platform, in order to facilitate the ordering and purchasing process. So that consumers can interact with MSME owners to make transactions directly. The results of this study suggest that MSME have to understand and add insight into the importance of digital marketing strategies to support the sustainability of MSME businesses. Digital marketing is an opportunity that can be developed to achieve maximum business benefits during the COVID-19 pandemic.
\end{abstract}

Keywords: Social Media, Marketing, Promotion, Products, MSME

\section{A. Introduction}

The COVID-19 pandemic has a major impact on all aspects and sectors in people's lives, especially in the economic sector. Finance Minister Sri Mulyani said there were 3 major economic impacts on the COVID-19 pandemic. First, the impact on household consumption or people's purchasing power has fallen. Second, investment has also weakened amid the uncertainty of the COVID-19 pandemic. And third, the global economic downturn has stopped Indonesia's exports (Sitomorang, 2020). Due to the 
decline in community activities outside the home, this automatically results in a decrease in the number of buyers in a business. So that the income earned is reduced. This impact is not only felt by large industries, the Corona virus pandemic also has an impact on Micro, Small and Medium Enterprises (MSMEs) in Indonesia.

The impact of COVID-19 on MSMEs is also experienced by DKI Jakarta. There are around 124 MSMEs owned by residents of Jakarta. Consisting of culinary, sewing services and grocery stores. According to the survey we have conducted, all MSME actors in Jakarta have had a significant impact from the COVID-19 pandemic, from the husband who lost his job due to layoffs to the decline in the number of buyers. In this condition, it is necessary to have innovation and creativity for MSME actors to market their products online by utilizing social media.

Along with technological developments, one of which the internet has changed the way of interaction in marketing communication from face to face (conventional) to screen to face (internet marketing). This is due to the increase in internet users and users of social media accounts in Indonesia which have an impact on increasing interest in shopping online (Nisaputra, 2013). According to Bloom \& Boone (2006), the current use of the internet is not only for research purposes, but as a source of news, playing online games, as a means of socialization and as a business. In addition, purchasing via the internet is widely used nowadays, for reasons of saving time.

It can be said that the internet is indeed very practical and easy to use when the routine is tight in today's digital era. In a product marketing communication both through online (screen to face) and conventional marketing (face to face), a communication strategy is very necessary. The right marketing communication strategy can prevent companies from losses caused by ineffective and efficient promotional activities (Soemanagara, 2006). Internet marketing is one of the tools in marketing communication that is currently widely used as a new medium in the marketing world, one of which is by utilizing the popularity of social media as a promotion medium.

Choosing the use of marketing through social media is the main choice made by business actors during the Covid 19 pandemic, because this can limit direct contact with customers. In addition, nowadays the use of social media has become the main pillar in delivering information. One of the advantages of social media is that it has a lot of potential for the advancement of a business. Social media can be used to communicate in business, help market products and services, communicate with customers and suppliers, complete brands, reduce costs and for online sales (Achmad \& Setiyanti, 2015) 
The Role of Social Media in Marketing of Micro, Small, and Medium Enterprise...

There are several social media that are currently booming, including Whatsapp, Instragam, TikTok, Twitter, Line, Telegram, Facebook, Youtube, and others. Someone must have various motivations in using social media. Just to communicate with other people, to find out the development of something, to share information and to follow one of the current trends, namely using social media as a form of self-existence.

When the COVID-19 pandemic occurs and is still ongoing, the number of uses will continue to increase in line with the physical distancing policy that allows people to carry out their activities online. Therefore, social media can be used as a tool to develop and optimize businesses, especially micro, small and medium enterprises (MSMEs), especially to promote their businesses.

Recently, Instagram and TikTok have begun to be of interest to Indonesians as social media accounts that have visual uses such as uploading photos and videos. The phenomenon of Instagram and TikTok in Indonesia has made the number of active users increase from 2013 (teknojurnal.co).

The use of online shopping services in Indonesia has increased in the last three years. The 2007 Nielsen Global Online survey placed Indonesia in 13th place out of 14 Asia Pacific countries, with 51 percent of the internet user population who had shopping online. Catherine Eddy, Executive Director of Client Solutions Nielsen Indonesia, explained that the biggest buyers via the internet are still controlled by developing countries. So he is sure that the number of online shopping users in Indonesia will grow gradually (Wijaya, 2008).

Based on the data released by Nielsen above, it can be said that the flow of globalization is making people even busier with their routines, so that the internet is used as an alternative tool to get their daily needs. According to Kotler (2001), online media marketing is in demand because it has several benefits for consumers. Purchasing online is convenient, customers don't have to grapple with traffic, find a parking space, and walk from store to shop and consumers can order goods 24 hours a day from anywhere and at any time. In addition, according to Kotler, online purchases are interactive and immediate, namely buyers can interact with the seller's site to find information and then place orders on the spot. This shows that currently some people are comfortable shopping online because it can be accessed easily and is hassle-free.

In this research, DKI Jakarta was chosen as the object of this research because it is based on the large number of internet users who place the city of Jakarta as the first largest city of internet users in Indonesia in 2020 based on the APJII survey (Indonesian 
Internet Service Provider Association). In addition, the city of Jakarta is the center of business, trade and industry in Indonesia (www.eastjava.com), as well as a big city in terms of MSMEs (NewsWire, 2012). So it is interesting to see how the strategies are implemented by MSME owners in the city of Jakarta as a trading center in Indonesia. Furthermore, this research was conducted during the Covid 19 pandemic which greatly affected the sales conditions of MSMEs in Indonesia.

\section{B. Literature Review}

\section{Small and Medium Enterprises}

According to the Asian Development Bank (ADB) which was obtained from www.adbtasme.or.id, it sets limits for Small and Medium Enterprises based on the number of workers with the following conditions:

a) Small Business: the number of workers is between 5 and 19 people

b) Medium Enterprises: the number of workers is between 20 and 99 people

Some of the main capabilities of information technology include (Turban, 2001):

1) Perform numerical computations quickly and large volume capacity

2) Produce fast, accurate, and inexpensive communication within and between organizations

3) Large storage capacity in increasingly small and easily accessible media

4) Allows access to a lot of information quickly and cheaply, global scope

5) Improve the effectiveness of the performance of teams/groups that are spread out/ different locations

6) Automation of business processes

7) Speed of typing and editing

8) The above capabilities are carried out inexpensively compared to manual methods With this capability, information technology provides important support in business activities, including:

$\checkmark$ Increase productivity

$\checkmark$ Reducing costs

$\checkmark$ Improve the quality of decision making

$\checkmark$ Improve relationships with customers / consumers

$\checkmark$ Build new strategy applications 
The Role of Social Media in Marketing of Micro, Small, and Medium Enterprise...

In addition, small and medium enterprises are productive economic enterprises that are independent, carried out by individuals or business entities that are not subsidiaries or branches of companies that are owned, controlled, or are part of either directly or indirectly with Small or Large Businesses with the amount of net assets or annual sales proceeds as regulated in this Law.

Based on Law No. 20 of 2008 above clearly shows quite a large difference in terms of assets or turnover between micro and small businesses and small and medium enterprises. However, it is clear that overall MSMEs play a role in the development of the national economy, this is also in accordance with Law No. 20 of 2008 Chapter II, which reads: "Micro, small and medium enterprises aim to grow and develop their businesses in the context of building a national economy based on just economic democracy."

\section{Social Media}

Social media is a site that makes it easier for everyone to communicate, participate, exchange information, and form an online network with their friends and relatives, both those they know in the real world and cyberspace, which can be called social networking media. In their article on Horizons Bisnis published in 2010, Kaplan and Haenlein classified the types of social media into 6, namely: collaboration projects (for example wikipedia), blogs and microblogs (for example twitter), content communities (for example youtube), social networking sites (for example facebook, instagram), virtual games (for example world of warcraft), and virtual social (for example second life) (Kaplan, A. \& Haenlein, M, 2010).

Social media is a tangible form of new media (new media) based on advances in communication technology supported by information and communication technology (Information and Communication Technology). Social media is understood as a new form of communication on the internet that is supported by various software applications, which allow interaction between users. Social media has several advantages, especially in its ability to provide interactive two-way communication, and make it easier for its users to access various kinds of information.

This condition will greatly support interactive communication without obstacles and distances. In it, it is possible to have social interaction between individuals, individuals with groups, groups with groups, even individuals and groups in bulk.

\section{E-Commerce}

The use of the internet for various business activities is called E-Commerce. Business activities carried out online can include marketing, promotion, public relations, 
transactions, payments, and scheduling of delivery of goods, as well as the possibility of innovating online business activities along with the development of e-commerce technology itself.

\section{Research Methods}

This descriptive qualitative research uses a phenomenological approach. The phenomenological method seeks to understand the meaning of events and their relation to people in certain situations. The phenomenological method emphasizes subjective experiences or phenomenological experiences (Haq, I. B., 2019). Researchers aim to explore descriptive phenomena by observing, understanding and collecting data, analyzing and making conclusions about a phenomenon. The qualitative descriptive research approach is one of the types of research that provides a full picture of the social situation or the relationship between the phenomena being studied (Sugiyono, 2015). The qualitative method is expected to be able to produce an in-depth description of speech, writing, and observable behavior of an individual, group, community, or organization in a particular setting context that is studied from a complete, comprehensive and holistic point of view (Ruslan, R. 2010). This study observes and describes the understanding of the use of social media in the development of MSMEs in businesses in DKI Jakarta.

The data obtained will be analyzed qualitatively, namely the analysis carried out by understanding and arranging the data that has been collected and arranged systematically, then conclusions are drawn. In qualitative research, the conclusions generated are generally not intended as generalizations, but as an interpretive description of the reality or symptoms that are studied holistically in a particular setting (Achmad, Z. A \& Ida, R, 2018). The results are basically limited to the cases observed. Therefore, the principle of inductive thinking is more prominent in drawing conclusions in qualitative communication research. The data collection technique used questionnaires and direct interviews to eleven MSME owners in DKI Jakarta as informants.

In this study the informants were taken purposively with the emphasis that the informants had sufficient knowledge about the use of the internet as a promotional media for marketing clothing products by businesses in DKI Jakarta. These informants are people in the Jakarta area who can provide information about the situation and conditions of the research background. 
The Role of Social Media in Marketing of Micro, Small, and Medium Enterprise...

The method for selecting informants was carried out by researchers in the first step, namely the researchers deepened the use of the internet as a media for marketing promotion of MSME products. The next step is to use certain approaches to MSME owners and consumers to obtain information that will describe people who can be selected as informants in relation to the use of the internet as a media for marketing their products marketing promotion. The next step is to dig deeper into the information to find enough people as informants in the researcher.

Armed with preliminary information, researchers conducted interviews with people who had been designated as informants via telephone, WhatsApp, and email, made observations of several people in activities related to the use of the internet as a medium for promoting UMKM products. This is done to test the correctness of the information that has been obtained. The informants involved in this research are sellers or owners and consumers because they feel how to use or buy products via the internet.

The data in this study used the interactive model data analysis by Miles and Huberman, namely that there were three processes that took place interactively. First, data reduction, which is the process of selecting, focusing, simplifying, and abstracting data from various data sources, namely from interviews and observation notes.

Then the process of emphasizing, shortening, removing unnecessary, determining focus and organizing data so that conclusions can be made. This is part of the data reduction process. Second, presenting data, such as assembling data and presenting it properly so that it is easier to understand. Presentation can be in the form of matrices, pictures / schemes, networks, tables and so on. Third, draw conclusions / tests, the process of drawing initial conclusions is still not strong, sharpened by revising and sharpening the analysis.

The final conclusion is made after the data collection ends. Data testing can be done through peer-to-peer discussion, and checking the data back carefully.

\section{Results and Discussion}

Based on the results of our interviews with MSME actors, it is known that there are 124 MSMEs in DKI Jakarta that will be examined in this study. Information from the interview results above shows that MSME actors in DKI Jakarta are on average run by housewives who have been running their UMKM for more than 2 years and also teenagers. And the main problem of MSME players in DKI Jakarta during the current COVID-19 pandemic, all MSME players are being affected by the economy, namely 
experiencing a decline in sales and demand for goods or services from consumers. Currently, the promotions carried out by 124 MSMEs in DKI Jakarta have been through direct person-to-person promotions and broadcast WhatsApp, Instagram and TikTok, but there are also 40 MSMEs using Facebook.

\section{The Use of Social Media for Promotion}

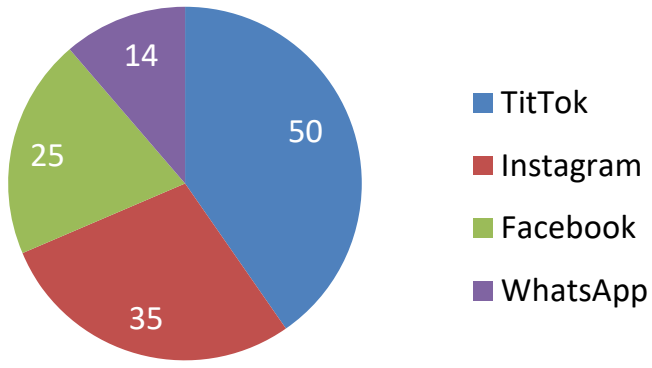

Figure 1. Types of Social Media Used by MSME Players in DKI Jakarta

Promotion through social media has been carried out a lot because MSME owners in Jakarta are already literate in managing social media and the ease of accessing social media facilities. Thus, of course, the right innovation is needed in increasing or rising from a decline in product sales. One of the strategies in product marketing carried out during the current pandemic is to take advantage of social media so that the reach of product or service promotions becomes wider. In times of the COVID-19 pandemic like today, social media is the platform that is most accessed by everyone. In addition, accessing social media can easily be done by all groups, from the old to the young. So, by carrying out even more tipsy promotions on social media, of course, it can increase marketing even though the results of the sales promotions carried out have not increased significantly considering the relatively short application period.

DKI Jakarta MSME actors are quite diverse in using social media, such as Facebook, TikTok, and Instagram. If seen in the graph, MSME players in DKI Jakarta often use TikTok because it is easy for some MSMEs players. In addition, promotions using TikTok can be done in a more attractive manner accompanied by popular music videos. There are also using Instagram, Facebook, and WhatsApp because the social media has already been controlled by MSME players. Based on Figure 1, as a whole, DKI Jakarta MSME actors promote goods or services they sell by offering directly to prospective customers because this method is considered easy, cheap and both producers and consumers can directly see the products sold on the sisoal media platform, so that it can cause trust 
The Role of Social Media in Marketing of Micro, Small, and Medium Enterprise...

between the two because it is also accompanied by honest testimony. This method is very effective when there is a COVID-19 pandemic that is happening at this time, due to the policy of maintaining physical distancing which aims to minimize the spread of COVID19 which is increasingly widespread. So that many people switch to using social media platforms to find information on goods or services offered that they feel safer.

\section{Product Promotion on Social Media}

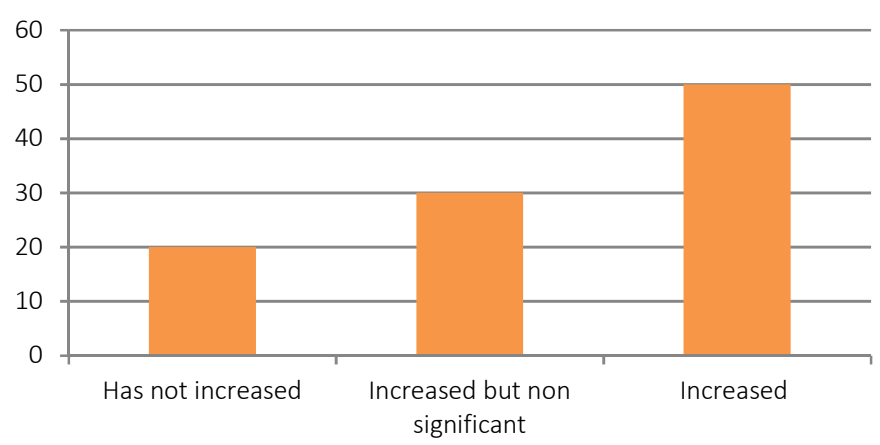

Figure 2. The Effect of Product Promotion on Social Media

Since the COVID-19 pandemic, everyone has been required to maintain physical distancing so that it is not possible for DKI Jakarta MSMEs to promote products directly from person to person. Therefore, it is necessary to have a new marketing strategy so that the business that is being undertaken can survive during the COVID-19 pandemic. Various platforms have been provided, such as Facebook, Twitter, TikTok, Instagram and so on.

\section{E. Conclusions}

Based on the results of research conducted by researchers regarding the role of social media as a promotional media for MSME products in DKI Jakarta, researchers can draw conclusions, namely:

1. MSME players take advantage of internet media by doing direct marketing of their products on the internet by providing special offers and guarantees for products that have been sold because the products displayed on their website are sometimes not in accordance with buyer expectations by displaying information about special offers and warranty on the website owned.

2. Social media platforms play an important role in marketing MSME products in DKI Jakarta during the COVID-19 pandemic. 
3. MSME players in DKI Jakarta have optimized the marketing of UMKM products through social media. Most of the MSME players have used social media for marketing but it is still on a small scale and is not well organized. The trial of optimizing the use of social media as a good product marketing tool for MSME players in DKI Jakarta can re-increase the sales figure of MSME products, and reach consumers on a large scale.

4. Utilization of social media as an effective means of support for the operation of MSMEs during the COVID-19 pandemic because MSME players in DKI Jakarta can still carry out their business activities by still complying with and implementing health protocols.

The results of this study suggest that MSME players understand and add insight into the importance of digital marketing strategies to support the sustainability of MSME businesses. Digital marketing is an opportunity that can be developed to achieve maximum business benefits during the COVID-19 pandemic.

\section{Bibliography}

Achmad, Z. A., \& Ida, R. (2018). Etnografi Virtual Sebagai Teknik Pengumpulan Data dan Metode Penelitian. The Journal of Society and Media, 2(2), 130-145.

Achmad, Z. A., \& Setiyanti, O. W. (2015). The Effectiveness of Use of Soundcloud Application for Promoting Pop Punk Songs and Music. Bali International Seminar on Science and Technology (BISSTECH), 59-64.

Ardiyanto, A. (2018). Analisis Penggunaan Media Sosial dalam Pengembangan Usaha Mikro, Kecil, dan Menengah (UMKM) di Desa Kemasan Kecamatan Sawit Kabupaten Boyolali. Surakarta: Fakultas Ekonomi dan Bisnis Islam, Manajemen Bisnis Syariah, Institut Agama Islam Negeri Surakarta.

Bloom, P. N., \& Boone, L. N. (2006). Strategi Pemasaran Produk. Jakarta: Prestasi Pustaka.

Haq, I. B. (2019). Henna Sebagai Komunikasi Identitas Budaya (Studi Fenomenologi Pemahaman \& Pemaknaan Laki-Laki Pengguna Henna di Kampung Arab Surabaya). Jurnal Voxpop, 1(1), 98-107.

Kaplan, A. M., \& Haenlein, M. (2010). User Of The World, Unite! The Challenges and Opportunities of Social Media. Business Horizons, 53(1), 59-68.

Kotler, P., \& Amstrong, G. (2001). Dasar-dasar pemasaran (2 ed.). (A. Sindoro, Trans.) Jakarta: Erlangga.

Nisaputra, R. (2013, April 1). 36 Juta Jiwa Aktif Menggunakan Bisnis Online. Retrieved Mei 6, 2013, from Oke Finance: https://economy.okezone.com/ 
The Role of Social Media in Marketing of Micro, Small, and Medium Enterprise...

Ruslan, R. (2010). Metode Penelitian Public Relations dan Komunikasi (5 ed.). Jakarta: Rajawali Pers.

Situmorang, A. P. (2020, June 30). Sri Mulyani: Corona Beri 3 Dampak Besar ke Ekonomi Indonesia. Retrieved July 1, 2020, from Liputan 6: https://www.liputan6.com/

Soemanagara, R. (2006). Strategic Internet Marketing: Konsep Strategis dan Terapan. Bandung: Alfabeta.

Sugiyono. (2015). Metode Penelitian Kuantitatif, Kualitatif, dan R\&D. Bandung: Alfabeta. 